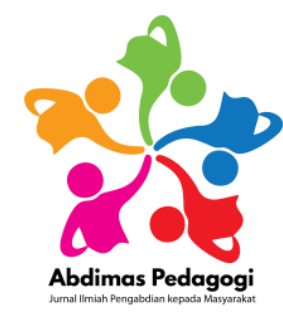

Abdimas Pedagogi: Jurnal Ilmiah Pengabdian kepada Masyarakat

Vol 2, No. 3, 2019, hlm.155-163

ISSN 2615-3122 (online)

ISSN 2548-6683 (print)

\title{
PENDEKATAN PARTICIPATORY PLANNING PADA PERENCANAAN RUANG BELAJAR PENDIDIKAN ANAK USIA DINI (PAUD)
}

\author{
Julindiani Iskandar*, Dedes Nur Gandarum \\ Jurusan Arsitektur, FTSP Universitas Trisakti, Jakarta, Indonesia \\ Jl. Kyai Tapa No. 1, Grogol, Jakarta, Indonesia \\ *e-mail: lhamanov@gmail.com
}

\begin{abstract}
Planning for Ananda's Early Childhood Education (PAUD) learning room, located in a densely populated and densely populated residential district of Tambora District, West Jakarta, was carried out due to lack of knowledge and funds to build and carry out maintenance. Therefore, additional knowledge, assistance and a pilot of healthy learning environment facilities are needed. Counseling, assistance and demonstration conducted are bottom up through a participatory planning approach. This is done so that the planning, design, and maintenance of environmental facilities are in accordance with the needs and abilities of the community, can be accepted by the community, as well as a medium for community learning or transfer of knowledge related to the planning, design and maintenance of environmental facilities, especially PAUD facilities. In addition, with this participatory approach it is hoped that a strong sense of ownership will emerge as a basis for self-supporting and sustainable maintenance and development of public facilities.
\end{abstract}

Keywords: Planning; study space; participatory planning

\begin{abstract}
Abstrak: Perencanaan ruang belajar Pendidikan Anak Usia Dini (PAUD) Ananda yang terletak di pemukiman padat penduduk dan padat bangunan Kecamatan Tambora, Jakarta Barat dilakukan karena kurangnya pengetahuan dan biaya untuk membangun dan melakukan perawatan. Oleh sebab itu diperlukan pengetahuan tambahan, pendampingan serta percontohan tentang fasilitas lingkungan belajar yang sehat. Penyuluhan, pendampingan serta percontohan yang dilakukan bersifat bottom up melalui pendekatan partisipatory planning. Hal ini dilakukan agar perencanaan, perancangan, dan perawatan fasilitas lingkungan tersebut sesuai dengan kebutuhan dan kemampuan masyarakat, dapat diterima oleh masyarakat, serta menjadi media pembelajaran masyarakat atau transfer of knowledge terkait perencanaan, perancangan, dan perawatan fasilitas lingkungan, khususnya fasilitas PAUD. Selain itu dengan pendekatan partisipatif ini diharapkan timbul rasa kepemilikan yang kuat (sense of belonging) yang akan menjadi modal dasar bagi pemeliharaan dan pengembangan fasilitas publik secara swadaya dan berkelanjutan.
\end{abstract}

Kata kunci: Perencanaan; ruang belajar; partisipatory planning 


\section{PENDAHULUAN}

Masalah permukiman bagi masyarakat berpenghasilan rendah semakin lama semakin kompleks, seperti kerusakan lingkungan dan tidak produktifnya penggunaan lahan di perkotaan. Bagi masyarakat berpenghasilan rendah, masalah yang mereka hadapi tidak hanya kesulitan dalam memenuhi kebutuhan akan rumah saja, melainkan juga masalah lingkungan permukimannya juga, seperti kurangnya jumlah fasilitas lingkungan permukiman seperti: infrastruktur yang memadai, MCK (Mandi Cuci Kakus), rumah ibadah, pos yandu, sekolah, taman bermain anak-anak, pos jaga dan lain-lain. Selain itu, fasilitas-fasilitas lingkungan yang tersedia sebagian besar tidak memenuhi standard kelayakan (baik kuantitas maupun kualitasnya) dan sering tidak terawat.

Permukiman di Kecamatan Tambora merupakan pemukiman padat penduduk dan padat bangunan. Kurangnya ketersediaan fasilitas lingkungan serta kurangnya pengetahuan dan biaya untuk membangun dan merawatnya menyebabkan perlunya pengetahuan tambahan, pendampingan serta percontohan tentang fasilitas lingkungan yang sehat. Penyuluhan, pendampingan serta percontohan yang akan dilakukan bersifat bottom up melalui pendekatan partisipatory planning. Hal ini dilakukan agar perencanaan, perancangan, dan perawatan fasilitas lingkungan tersebut sesuai dengan kebutuhan dan kemampuan masyarakat, dapat diterima oleh masyarakat, serta menjadi media pembelajaran masyarakat atau transfer of knowledge terkait perencanaan, perancangan, dan perawatan fasilitas lingkungan, khususnya fasilitas PAUD. Selain itu dengan pendekatan partisipatif ini diharapkan timbul rasa kepemilikan yang kuat (sense of belonging) yang akan menjadi modal dasar bagi pemeliharaan dan pengembangan fasilitas publik secara swadaya dan berkelanjutan.

Sinergi antara masyarakat, pemerintah, dan perguruan tinggi sebagai agen pembangunan sangat penting dalam mengelola lingkungan binaan dalam rangka mewujudkan kehidupan yang berkualitas bagi pertumbuhan dan perkembangan bangsa secara keseluruhan. Pendekatan Partisipatory Planning dilakukan agar mampu menjembatani perbedaan kepentingan dan kebutuhan antar agen pembangunanserta memanfaatkan sumberdaya pembangunan yang dimiliki oleh masing-masing agen pembangunan tersebut tersebut dalam mengelola (membangun, memanfaatkan, dan merawat) fasilitas publik yang ada di Kecamatan Tambora, khususnya fasilitas pendidikan usia dini (PAUD). Selain itu pendekatan perencanaan partisipatif ini dapat menjadi media pembelajaran masyarakat atau transfer of knowledge terkait perencanaan, perancangan, dan perawatan fasilitas lingkungan, khususnya fasilitas PAUD. Diharapkan pendekatan partisipatif mampu menimbulkan rasa kepemilikan yang kuat (sense of belonging) yang akan menjadi modal dasar bagi pemeliharaan dan pengembangan fasilitas publik secara swadaya dan berkelanjutan.

Kegiatan ini diharapkan dapat memberikan stimulus kepada masyarakat tentang pentingnya mewujudkan lingkungan yang berkualitas, serta perlunya aksi bersama agar pembangunan, pemanfaatan, dan pemeliharaan fasilitas publik, khususnya PAUD di Kecamatan Tambora dapat efektif dan efisien.

\section{Pendekatan Participatory Planning}

Pembangunan yang dilakukan untuk memenuhi kebutuhan masyarakat dalam rangka meningkatkan kesejahteraannya, hendaknya melibatkan seluruh lapisan masyarakat sebagai subyek pembangunan, dengan cara mengutamakan peran serta masyarakat sejak tahap perencanaan sampai tahap pemeliharaan hasil pembangunannya. Hal ini merupakan suatu wujud penghargaan terhadap kemampuan, harkat, dan martabat masyarakat.

Suatu kegiatan pembangunan terdiri dari tahap perencanaan, tahap perancangan, tahap konstruksi, tahap operasional dan pemeliharaan. Perencanaan partsitipatif diartikan sebagai 
terlibatnya berbagai aktor pembangunan, yang terdiri dari masyarakat, pemerintah, dan swasta, yang difasilitasi dan dimotivasi oleh perguruan tinggi sebagai institusi pengembangan Ipteks pada setiap tahapan pembangunan, sesuai dengan sumberdaya pembangunan yang dikuasainya. Pelibatan atau keikut-sertaan masyarakat yang berkepentingan dengan hasil pembangunan, pada setiap tahapan pembangunan sangatlah penting, agar pembangunan yang yang dilakukan dapat lebih didasarkan pada kajian-kajian terhadap masalah yang dihadapi dan potensi yang tersedia di dalam masyarakat. Melalui metode perencanaan partisipatif diharapkan akan ada hubungan yang erat antara masyarakat dengan kelembagaan masyarakat secara terus menerus. Masyarakat diberi kesempatan untuk menyatakan masalah yang dihadapi dan gagasan-gagasan sebagai masukan untuk berlangsungnya proses perencanaan berdasarkan kemampuan warga masyarakat (http://studyandlearningnow.blogspot.com, 2013).

Pada prinsipnya, perencanaan partisipatif merupakan metode atau cara perencanaan yang memfungsikan kelembagaan masyarakat secara nyata di dalam setiap tahapan pembangunan, sesuai dengan sumberdaya pembangunan yang dikuasainya. Dengan cara ini diharapkan masyarakat mau dan mampu melaksanakan, memelihara, dan menindak-lanjuti hasil-hasil pembangunan. (http://studyandlearningnow.blogspot.com, 2013)

Penerapan metode pendekatan perencanaan partisipatif diharapkan dapat menampung semua permasalahan dan potensi yang ada masyarakat. Dengan metode ini dapat diperoleh suatu gambaran umum yang akurat mengenai keadaan dan situasi obyek atau kawasan pembangunan serta aspek-aspek kehidupan masyarakat yang perlu mendapat perhatian khusus dalam melaksanakan pembangunan di desa. Dalam metoda perencanaan partisipatif ini dimungkinkan semua warga atau kelompok dalam masyarakat berhak dan dapat berperan dalam pembangunansesuai dengan kebutuhan dan permasalahan nyata yang dihadapi masyarakat.

Kegagalan metoda partisipatif ini, yang antara lain ditandai dengan muncul dari adanya masyarakat yang tidak tergerak untuk mendukung atau berpartisipasi dalam suatu program atau kegiatan pembangunan, antara lain disebabkan oleh: (http://studyandlearningnow.blogspot.com, 2013): masyarakat tidak diikutsertakan sejak dari penyusunan perencanaan program pembangunan, masyarakat belum cukup mendapatkan penghargaan berupa kesempatan, dan penghargaan terhadap partisipasi yang layak, kemampuan masyarakat yang terbatas, kurang memberikan hasil yang diharapkan, tata nilai dan budaya masyarakat yang belum siap untuk mampu berpartisipasi aktif dalam pembangunan, suatu pembangunan dengan pendekatan partisipatory yang berhasil ditandai dengan (http://studyandlearningnow.blogspot.com, 2013): terjalinnya hubungan yang terus menerus antara aktor-aktor pembangunan (masyarakat, pemerintah, swasta, dan institusi pendidikan), masyarakat atau kelompok masyarakat berperan penting dalam pengambilan keputusan, mulai dari merumuskan permasalahan yang dihadapi sampaimengemukakan gagasangagasan pemecahan permasalahan sebagai masukan berharga, setiap tahapan pembangunan dari perencanaan, pembangunan, pemanfaatan, dan pemeliharaan berlangsungsesuai dengan kemampuan warga masyarakat itu sendiri.

\section{Konsep Pembelajaran Sentra Bermain}

Agar kondisi otak anak selalu dalam keadaan yang menyenangkan, maka bermain sebagai bentuk kegiatan belajar di taman kanak-kanak merupakan bermain yang kreatif dan menyenangkan (tidak menimbulkan rasa takut pada diri anak). Untuk mendukung kegiatan tersebut haruslah disediakan sarana yang sesuai dengan kebutuhan dan minat anak.

Kreativitas anak usia dini pada dasarnya dapat dikembangkan dengan berbagai cara, khususnya di PAUD. Salah satu strategi pembelajaran yang mendukung tumbuh kembang dan 
tahapan cara berpikir anak adalah strategi pembelajaran berbasis sentra bermain. Pembelajaran berbasis sentra bermain adalah model pembelajaran learning by doing, learning by stimulating, dan learning by modeling. (Nurani, Sari: 2017).

Pembelajaran berbasis sentra bermain sangat menarik bagi anak, di mana anak dapat memilih kegiatan pembelajaran sesuai dengan minatnya. Sentra bermain merupakan pusat sumber belajar berupa wahana yang dirancangkan untuk merangsang berbagai aspek perkembangan pada anak usia dini. Sentra bermain ini juga merupakan media pembelajaran, yaitu alat yang digunakan untuk menunjang kegiatan proses pembelajaran. Fakta menunjukkan bahwa kegiatan belajar dengan sentra bermain ini mampu meningkatkan kreativitas anak. (Nurani; Sari, 2017).

\section{Peran Warna pada Interior PAUD}

Perencanaan dan perancangan perbaikan fasilitas PAUD juga merujuk pada beberapa pertimbangan penting, yaitu peran warna pada ruang belajar usia dini serta konsep belajar dengan sentra bermain.

Pada fase usia dini, baiasanya, anak-anak sedang mengalami perkembangan fisik, kognitif, emosi dan sosial yang cepat, yang akan sangat berpengaruh pada petumbuhan dan perkembangan selanjutnya. Lembaga pendidikan Pendidikan Anak Usia Dini merupakan salah satu sarana yang ditujukan untuk memberikan dukungan pertumbuhan dan perkembangan anak.Selain kualitas guru dan kurikulum, maka lingkungan fisik yang kondusif bagi proses pembelajaran merupakan faktor penting dalam mendukung perkembangan anak..

Ruang kelas sebagai tempat belajar dan taman belajar dibangun untuk mewadahi sebagian besar program kegiatan belajar anak usia dini, dimana anak-anak tumbuh dan berkembang baik secara fisik, intelektual maupun emosional. Secara psikologis, interior ruang kelas, dapat merangsang serta memotivasi anak untuk aktif bermain sambil belajar sesuai dengan tahapan perkembangan mereka (Sari, 2004) Untuk menciptakan lingkungan belajar yang kondusif yang mendukung perkembangan fisik dan mental anak maka faktor penataan ruang kelas seperti pemilihan jenis, ukuran, dan penataan perabot, warna, kenyamanan thermal-audio-visual, menjadi sangat penting. Ruang belajar yang indah, inspiratif, dan menyenangkan mampu mendorong anak menjadi kreatif, didukung dengan warna-warna terang.

Dalam menciptakan suasana ruang, peran warna sangatlah penting, karena suatu komposisi warna dapat menimbulkan suasana yang menyenangkan yang pada gilirannya dapat meningkatkan kualitas proses belajar anak. Hasil penelitian menunjukkan bahwa penggunaan warna interior ruang kelas yang tepat dapat meningkatkan kinerja belajar mengajar. Dalam hal ini warna mampu menimbulkan kesan-kesan tertentu untuk menciptakan suasana ruang tertentu. Selain itu warna juga dapat mempengaruhi jiwa anak-anak, misalnya perasaan nyaman, gelisah, panas, dan sebagainya. Oleh karenanya perlu diketahui pengaruh warna-warna tertentu terhadap anak-anak, untuk mencegah terjadinya penggunan warna- warna yang berpengaruh negatif, khususnya terhadap perkembangan fisik dan mental anak. Dapat disimpulkan bahwa Interior ruang kelas dengan warna sebagai salah satu elemennya dapat berperan dalam membangun lingkungan belajar anak yang kondusif, untuk menstimuli semangat belajar sehingga perkembangan anak dapat optimal (Sari, 2004).

Dibutuhkan kualitas suasana ruang belajar yang memadai untuk memenuhi kebutuhan perkembangan anak, yaitu kebutuhan akan rasa bebas, aman, stimuli, nyaman dan hangat. Ruang belajar haendaknya memberikan kemudahan bagi anak-anak untuk beraktivitas di dalam sebuah ruang dengan bebas, untuk mendukung perkembangan psikologisnya. Selain itu sebuah ruang belajar hendaknya memiliki suasana yang sesuai dengan kondisi fisik dan psikologis anak. Tidak 
kalah pentingnya, adalah bahwa ruang belajar harus mampu memberikan rasa aman kepada seorang anak ketika melakukan kegiatan, tidak berada dalam suasana menakutkan dan menegangkan.

Ruang belajar yang nyaman mampu mengkondisikan seorang anak untuk tetap beraktivitas selama ia mau dan mampu untuk melakukannya, tidak merasa terasing dan bosan. Kenyamanan ruang belajar ini dipengaruhi oleh pengolahan ruang. Ruang belajar yang nyaman sangat penting bagi perkembangan psikologis anak. Ruang belajar hendaknya juga mampu membantu proses perkembangan potensi anak melalui kegiatan-kegiatan kreatifnya. Sebuah ruang belajar, hendaknya ditata sedemikian rupa sehingga dapat menjadi sumber munculnya gagasan dan imajinasi anak-anak, sehingga membantu produktifitas anak yang berguna bagi perkembangannya (Sari, 2004).

Telah disebutkan terdahulu bahwa untuk anak usia prasekolah maka diperlukan suasana ruang belajar yang mampu memberikan suasana hangat, nyaman, bebas, rangsang dan aman, untuk memfasilitasianak-anak beraktivitas, berimajinasi dengan bebas, memotivasi dan memberikan inspirasi dalam setiap kegiatan kreatif anak-anak dalam rangka mendukung perkembangan psikologisnya. Ching (1996) menyatakan bahwa kebutuhan rasa bebas dalam ruang, diperlukan suasana ruang yang fleksibel, tidak terlalu padat dan didukung dengan warna terang dan warna netral, karena skema warna netral adalah yang paling fleksibel.

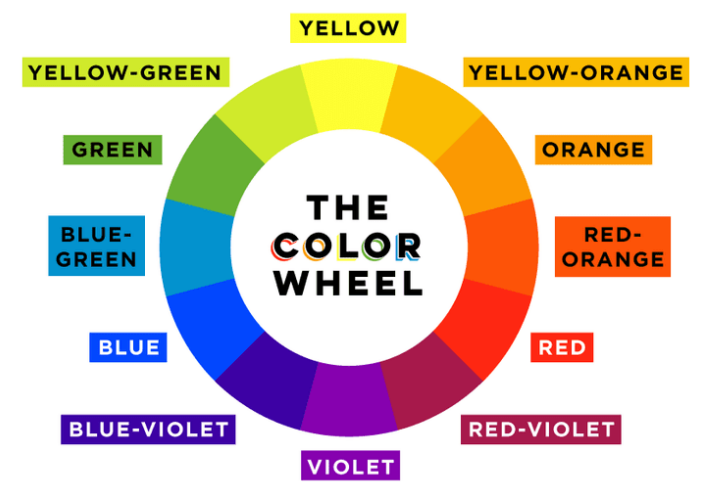

\section{Gambar 1. Skema gelap terang warna pada lingkaran warna (https://www.canva.com/, diakses 19 oktober 2018)}

Gambar 1 menampilkan skema gelap-terang warna pada lingkaran warna dalam pencahayaan normal. Tingkat pencahayaan dan kepekatan warna akan memberikan kesan kesan hangat atau dingin. Warna hangat dan intensitas tinggi bersifat aktif secara visual dan merangsang, sedangkan warna dingin dan intensitas rendah bersifat lebih tenang dan santai. Rasa aman dalam ruang, yaitu suasana ruang yang tidak menakutkan dan menegangkan, dapat diciptakan dengan menghindari warna hitam. (Sari, 2004). Ruang belajar yang aman dapat dipenuhi dengan penggunaan warna yang tidak menyilaukan sehingga tidak menyebabkan mata cepat lelah, sakit kepala dan tegang (Birren, 1961). Silau tidaknya warna terkait dengan intensitas warna atau chroma.

Penambahan warna putih dapat meningkatkan pencahayaan warna, sebaliknya penambahan warna hitam dapat menurunkan pencahayaan warna. Menambahkan warna putih dapat menimbulkan warna muda atau warna pastel, yang dibutuhkan anak untuk memenuhi rasa aman (Sari, 2004). Kebutuhan akan rasa nyaman dan hangat dalam ruang, dapat dicapaimelalui komposisi warna-warna hangat dengan intensitas rendah. Sedangkan penciptaan ruang yang dapat merangsang anak untuk beraktifitas, gembira dan kreatif dalamsuasana ruang hangat dan meriah, 
perlu didukung oleh warna-warna hangat, komposisi warna-warna kontras dan komposisi warnawarna terang (Sari, 2004 dan Birren, 1961). Warna-warna yang mendukung kebutuhan anak dalam sebuah ruang seperti tersebut di atas, agar program kegiatan dapat berjalan dengan baik dan perkembangan anak optimal, lebih dijelaskan dalam tabel berikut ini:

Warna dapat menjadi sarana untuk melatih keutuhan persepsi anak-anak terhadap ruang belajarnya. Penggunaan warna yang tepat dapat meningkatkan kinerja proses belajar mengajar, baik untuk siswa maupun gurunya. Warna dapat pulaberpengaruhpada jiwa anak-anak, misalnya perasaan gelisah, nyaman, panas, dan sebagainya. Sari (2004) menyatakan bahwa peran warna dalam mendukung program belajar mengajar di PAUD antara lain: menciptakan suasana emosional tertentu; berperan sebagai stimuli (rangsangan) beraktivitas dan berimajinasi, dengan menggunakan warna- warna cerah seperti merah, kuning, orange; warna merupakan sebuah elemen penting untuk mengevaluasi perkembangan anak; memfokuskan perhatian dengan warna yang menarik perhatian, dan mengalihkan perhatian, dengan warna coklat, abu-abu; mengatur ruang agar tampak lebih luas atau mengecil, di mana warna dingin dapatterasa mundur dengan jarak lebih jauh, dan warna hangat, terutama keluarga merah akan terasa maju dengan kesan jarak yang lebih pendek; warna-warna cerah membuat objek nampak lebih besar dan ringan dari pada sesungguhnya. Sebaliknya warna gelap membuat obyek terasa lebih kecil dan berat; menciptakan rasa hangat, dingin, tenang dan riang. Penggunaan warna-warna cerah dan warna-warna kontras akan menciptakan suasana gembira atau riang.

\section{METODE}

Seperti telah disebutkan pada bagian terdahulu, bahwa metode pelaksanaan PKM penataan, perawatan, dan pemanfaatan ruang belajar PAUD ini, adalah pendekatan partisipatif, yang melibatkan empat pihak pemangku kepentingan (aktor pembangunan), yaitu masyarakat (pengguna PAUD), pemerintah setempat (pemilik PAUD), swasta (penyedia bahan bangunan), dan perguruan tinggi (pemilik Ipteks atau ilmu pengetahuan, teknologi, dan seni) yang mengkoordinasikan kegiatan. Masing-masing pemangku kepentingan tersebut menguasai sumberdaya pembangunannya masing-masing serta memiliki kebutuhan atau tujuan pembangunannya masing-masing (Gambar 2).

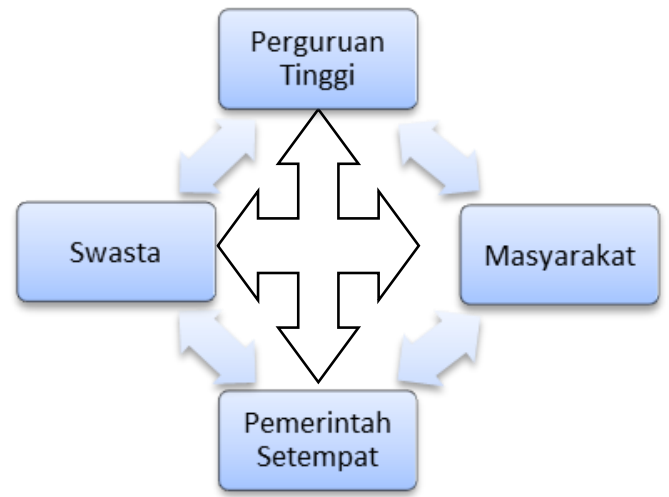

Gambar 2. Pihak-pihak yang berpartisipasi pada program penataan, pemeliharaan, dan pemanfaatan ruang belajar PAUD

Perguruan tinggi dengan sumberdaya intelektualnya berkepentingan untuk mendiseminasikan dan menerapkan ipteks yang dikuasainya untuk kepentingan peningkatan kualitas hidup (dan peradaban) masyarakat. Masyarakat berbekal hubungan sosial yang erat sebagai suatu komunitas serta tenaga kerja dapat berpartisipasi dalam program PKM ini untuk memenuhi kebutuhannya akan ruang belajar PAUD yang layak, yang sesuai dengan kurikulum 
yang berlaku. Pemerintah setempat (dalam hal ini RW dan Kelurahan) sebagai pemilik tempat dan pemberi ijin berkepentingan dengan peningkatan kualitas hidup masyarakat dan lingkungan yang berada di bawah tanggung jawabnya. Sedangkan pihak swasta dengan sumberdaya pembangunan yang dikuasainya (dalam hal ini bahan bangunan) dapat berperan dalam program PKM ini untuk tujuan menjalankan kewajiban CSR nya, serta sosialisasi produknya melalui percontohan penataan ruang PAUD dengan menggunakan produknya.

Dalam suatu program pembangunan biasanya terdiri dari tahap persiapan, tahap perencanaan, tahap pembangunan percontohan, tahap pemanfaatan (operasional), tahap perawatan (pemelihraan), tahap evaluasi. Dalam pelaksanaan Program PKM penataan dan perawatan ruang belajar PAUD secara partisipatif ini terdiri dari tahap perencanaan, tahap pembangunan percontohan, tahap pemanfaatan (operasional), tahap perawatan (pemeliharaan). Diharapkan pada tahap selanjutnya dapat dilakukan tahap evaluasi terhadap pemanfaatan dan perawatan ruang belajar PAUD.

\section{HASIL DAN PEMBAHASAN}

\section{Mitra Program PKM, PAUD ANANDA}

Survey awal dilaksanakan pada tanggal 27 September 2018, tim PKM berkunjung ke lokasi PAUD ANANDA bertemu dengan guru-guru pengurus dan guru PAUD yang baru akan mengajar. Pada saat survey pertama tim PKM datang ke lokasi setelah murid-murid PAUD sebelum belajar, atas permintaan guru-guru PAUD yang akan menerima kedatangan tim PKM.

Pada tahap konsultasi desain, tim PKM juga dibantu oleh mahasiswa-mahasiswa yang mengambil mata kuliah Klinik Arsitektur, dimana para mahasiswa diminta untuk melakukan praktek konsultasi desain dengan klien yang nyata. PKM di PAUD ANANDA adalah dianggap proyek yang akan di desain, dengan klien adalah guru-guru PAUD, orang tua murid dan anak-anak murid PAUD.

Sebelum memulai proses desain, tim PKM merencanakan mendata kebutuhan mitra PKM dengan melakukan wawancara dengan guru-guru PAUD, orang tua murid dan murid-murid PAUD sebagai pelaku utama kegiatan.

Konsultasi desain pertama dilakukan bersamaan dengan survey lokasi tangal 27 September 2018 untuk mendata kebutuhan pelaku kegiatan di PAUD ANANDA. Pendataan kebutuhan dilakukan sebelum guru-guru dan murid-murid memulai pelajaran dan pada saat murid-murid PAUD sedang belajar, dilakukan wawancara dengan orang tua murid yang menunggu anakanaknya.

Hasil pendataan kebutuhan PAUD ANANDA: 1) ukuran ruang kelas cukup luas untuk tempat belajar murid-murid PAUD; 2) kondisi fisik ruang kelas sangat diperlukan renovasi, karena sudah banyak yang rusak dan tidak layak untuk ruang belajar anak-anak PAUD, kondisi yang rusak antara lain: cat dinding yang sudah rusak dan mengelupas, cat plafon yang sudah mengelupas, kusen pintu dan jendela sudah rusak dan termakan rayap, kabel-kabel listrik yang sudah tidak layak dan berbahaya bagi keamanan anak-anak, papan tulis yang sudah rusak, tidak ada rak-rak buku / lemari untuk penyimpanan tugas, tidak ada kursi untuk guru, tidak ada rak sepatu, tidak ada tirai jendela; 3 ) kondisi ruang kelas yang tidak ada jendela (ventilasi) menjadikan suhu ruang kelas yang panas. Kipas angin yang dimiliki PAUD, kurang memadai, sehingga membutuhkan tambahan kipas angin yang diharapkan dapat merubah suhu ruang kelas menjadi lebih dingin; 4) keterbatasan kemampuan finansial PAUD ANANDA yang hanya menarik uang sekolah sebesar Rp.2,000,- per hari, menyebabkan PAUD ANANDA tidak bisa mewujudkan cara belajar sesuai kurikulum PAUD, yaitu belajar pada sentra-sentra, seperti : sentra profesi, sentra 
main peran, sentra balok keseimbangan, sentra seni, sentra musik dan gerak, sentra perpustakaan dan lain-lain; 5) kebutuhan untuk belajar dengan media video memerlukan alat untuk menayangkannya, misal LCD Proyektor atau TV dengan layar yang cukup besar; 6) rak-rak buku atau tempat penyimpanan mainan perlu di beli sesuai kebutuhan; 7) keinginan untuk mewujudkan sentra-sentra belajar seperti yang diminta oleh kurikulum PAUD, adalah unsur yang penting juga untuk diwujudkan dalam PKM ini (Gambar 3).

Setelah melakukan pendataan kebutuhan PAUD ANANDA dengan cara wawancara dan mendata langsung ke lokasi, tim PKM melakukan diskusi tentang desain ruang kelas PAUD yang akan dilaksanakan pekerjaan renovasinya. Diskusi desain ruang kelas PAUD ANANDA ini dilakukan di ruang dosen Jurusan Arsitektur FTSP Universitas Trisakti, gedung C, lantai 8, pada hari Selasa, tanggal 9 Oktober 2018 (Gambar 4)

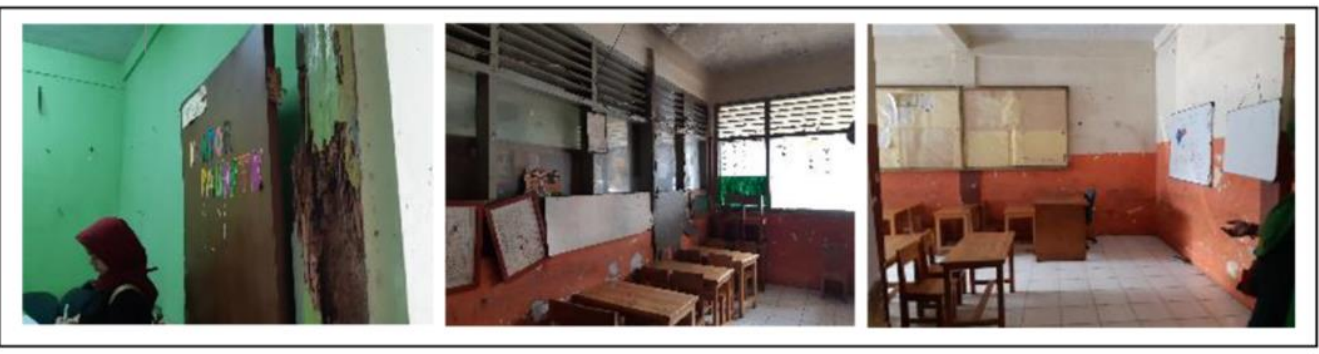

\section{Gambar 3. Kondisi sebelum dimulai pekerjaan}

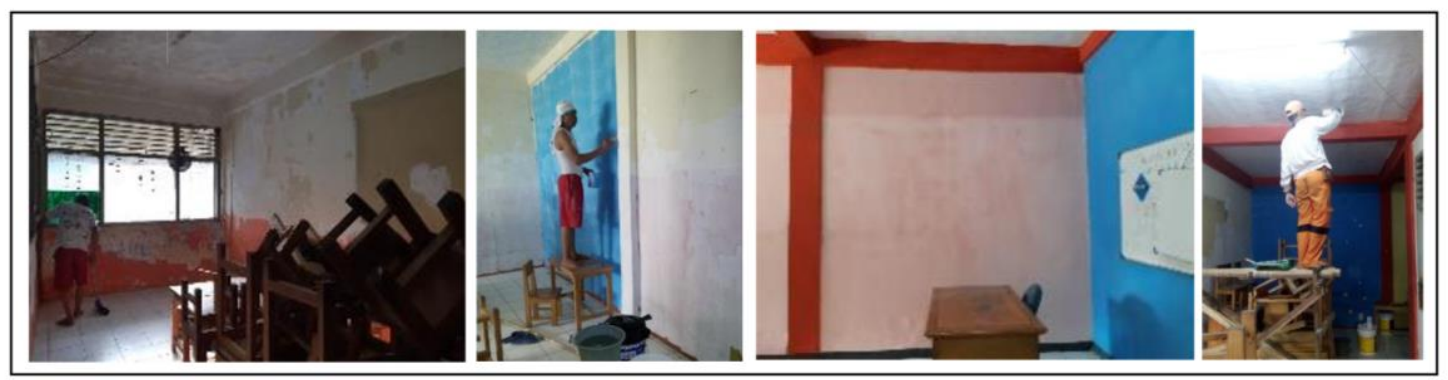

Gambar 4. Kondisi saat berlangsung pekerjaan dan setelah selesai pekerjaan

\section{SIMPULAN}

Kegiatan perencanaan ruang belajar PAUD Ananda dilakukan dengan metode penyuluhan, pendampingan, serta percontohan tentang fasilitas lingkungan belajar yang sehat melalui pendekatan participatory planning berhasil dilakukan yang dapat ditunjukkan dengan adanya rasa kepemilikan yang kuat (sense of belonging) yang kemudian menjadi modal dasar bagi pemeliharaan dan pengembangan sumber belajar yang merupakan fasilitas public secara swadaya dan berkelanjutan.

\section{DAFTAR RUJUKAN}

Birren, Faber. (1961). Colour Psychology and Colour Therapy. New York : University Books Inc Ching, Francis, D.K. (1996). Ilustrasi Desain Interior. Jakarta : Erlangga

http://studyandlearningnow.blogspot.com/2013/01/dasar-dasar-perencanaan-partisipatif.html, diakses 19 Oktober 2018

https://www.canva.com/id_id/belajar/teori-warna/, diakses 19 Oktober 2018

https://www.dekoruma.com/artikel/64511/prinsip-dasar-desain-arsitektur, diakses 27 Oktober 2018 
https://www.dekoruma.com/artikel/51959/trik-apik-ruang-tamu-kecil, diakses 27 Oktober 2018 https://elangfida.wordpress.com/2013/01/07/estetika/ diakses 28 oktober 2018

Kelurahan Angke. (2017). https://kelurahanangke.wordpress.com. diunduh 18 April 2017

Kelurahan Angke. (2016). Laporan Bulanan Kelurahan Angke Tahun 2016. Jakarta: Kelurahan Angke. Tidak Terpublikasi

Nurani, Y., \& Sari, M. (2017). Pengembangan Model Kegiatan Sentra Bermain dalam Mengembangkan Kreativitas Anak Usia Dini. Jurnal Pendidikan Usia Dini. DOI: https://doi.org/10.21009/JPUD.112. http://doi.org/10.21009/JPUD.112.15

Sari, S.M. (2004). Peran Warna Interior Terhadap Perkembangan dan Pendidik Anak di Taman Kanak-Kanak. Dimensi Interior, 2(1): 22-36

Winandari, MIR. (2014). Pemanfaatan Ruang Terbuka Publik Di Perumahan Dengan Tingkat Pendapatan Yang Berbeda Studi Kasus: Perumahan Menengah Atas Dan Perumahan Menengah Bawah Di Yogyakarta. Yogyakarta: Disertasi program pasca sarjana fakultas teknik. Tidak dipublikasikan. 